\title{
PROCUREMENT SELECTION CRITERIA FOR PROJECTS IN THE PUBLIC SECTOR: EVIDENCE FROM NIGERIA
}

\author{
Richard Ajayi Jimoh \\ Federal University of Technology, Minna, Nigeria \\ E-mail: rosney@futminna.edu.ng \\ Luqman Oyekunle Oyewobi \\ Federal University of Technology, Minna, Nigeria \\ E-mail: hassankay74@gmail.com \\ Nurayn Olanrewaju Aliu \\ Federal University of Technology, Minna, Nigeria \\ E-mail: aliulanren@gmail.com \\ Submission: 09/05/2016 \\ Revision: 03/06/2016 \\ Accept: 10/06/2016
}

\section{ABSTRACT}

The selection of suitable procurement practice for construction projects is a very complex and demanding tasks for stakeholders in the construction industry. In spite of the overabundance of techniques and tools accessible to the stakeholders in selecting an appropriate procurement method, clients are faced with the decision as to which of the selection criteria can be adopted for a given construction project to achieve project goals and objectives. This paper focused on evaluating the existing procurement methods being practised in the Nigerian construction industry with a view to identifying and establishing the parameters for selection that will improve contract delivery systems. In this research, quantitative approach was used to collect data from 420 contractors, consultants and clients based in the Federal Capital Territory, Abuja where large numbers of building projects are being procured. The findings revealed six most commonly considered criteria and deduced that, the quality, cost and duration of the project determines the type of procurement method to adopt. 
INDEPENDENT JOURNAL OF MANAGEMENT \& PRODUCTION (IJM\&P)

http://www.ijmp.jor.br

v. 7, n. 4, October - December 2016

ISSN: 2236-269X

DOI: 10.14807/ijmp.v7i4.481

It is therefore stated that in selecting any particular procurement method for building construction projects, the complexity of such project should be clearly defined and the other performance indicators be given adequate consideration for a successful project delivery that will enhance the achievement of the client's goal.

Keywords: Criteria, Construction, Procurement, Projects, Nigeria

\section{INTRODUCTION}

The procurement process for construction projects is a very difficult and demanding task from management perspective in the construction industry. The industry's inherent problems are as a result of its nature, structure and fragmentation, which is apparent most especially in the traditional separation of design and construction processes (BOWEN; PEARL; EDWARD, 1999). The unique nature of the industry coupled with the impermanent nature of project organisation places huge burden on the project team in making decisions as to which procurement process to adopt in building process and in achieving the overall objectives of the construction project.

Although, Love, Skitmore and Earl (1998) observed that there is a general agreement amongst researchers that certain procurement system is more appropriate for an individual project than all others, but there is no any procurement method that is better than the other in any project. Hence, the selection of suitable procurement system is largely dependent on the identification and establishment of client objectives and requirements (MASTERMAN; GAMESON, 1994).

However, there are various methods for bringing about building projects that are available to meet the needs of clients, but deciding on the method to use on a given project is a difficult and challenging task. This is as a result of the need to correlate client's objectives and priorities with the selected method in order to improve the chances of the project being procured successfully. In fact, studies (e.g. GORDON, 1994; NAOUM, 1994; LUU; NG; CHEN, 2005) have proposed that when an appropriate procurement system is selected, a reduction in the construction costs of project by an average of $5 \%$ is plausible which in turn increase the possibility of project success. 
INDEPENDENT JOURNAL OF MANAGEMENT \& PRODUCTION (IJM\&P)

http://www.ijmp.jor.br

v. 7, n. 4, October - December 2016

ISSN: 2236-269X

DOI: 10.14807/ijmp.v7i4.481

In spite of the importance of this process, many construction clients have resulted into selecting procurement methods superficially, and many clients often adopt a specific procurement system by default without making a purposeful choice.

Bowen et al. (1999) thus argued that wrongful selection or inappropriateness of the choice of procurement system may lead to project failure and that it forms one of the major factors responsible for the poor performance of the construction industry.

Therefore, considering the proliferation of differing procurement methods and the need to select and adopt more systematic methods of selecting suitable procurement system for a specific construction project (SKITMORE; MARSDEN, 1988), this paper examines the different procurement methods used for building projects in Nigeria; determines factors affecting the selection of a procurement method; establish the performance of each of the procurement methods in relation to set parameters of cost, time and quality.

\section{DETERMINANTS OF PROCUREMENT METHODS SELECTION}

It has been acknowledged that one of the fundamental justifications for the insignificant low level of performance of the construction industry is the inappropriate procurement method selected to procure the project (MASTERMAN, 1992; LOVE et al., 1998; BOWEN et al., 1999).

The client and their advisors are faced with daunting task of selecting the most suitable procurement method. Flexibility, certainty, complexity, quality, risk, price competition, responsibility, arbitration, dispute and time are the most common standard factors that influence the selection of procurement methods. However, these factors appear to be generic in nature while the situations are not the same across the globe.

The criteria for selecting different procurement strategies may be country specific and to believe that the circumstances are the same may be a recipe for potential failure of the process. For instance, the uprising buildings' intricacy, the demand for more efficient finance management, the need to cut down on design and construction time durations and the growing contract administration burden have placed added demand on the clients to find alternative routes to the traditional method. 
INDEPENDENT JOURNAL OF MANAGEMENT \& PRODUCTION (IJM\&P)

http://www.ijmp.jor.br

v. 7, n. 4, October - December 2016

ISSN: 2236-269X

DOI: 10.14807/ijmp.v7i4.481

Therefore, alternative procurement methods are being explored as a result of growing experience of most clients particularly as it concerns project's time, cost and quality performance criteria (MAIZON et al., 2006). Construction projects are full of twists and turns, they enjoy a long production cycle and involve several participants and they are susceptible to risks and uncertainties.

It is inherent for a client to have good experience and be fully aware of risks, how it has considerably been associated to another organisation, or in what manner it has been shared in some ratio between the clients and another essential need to them. Eradicating and lowering financial risk is considered as a critical requirement by clients. In theory, it is conceived to possess all design risks, management and time slippage or error handed to one organisation (MAIZON et al., 2006).

\section{FACTORS AFFECTING THE SELECTION OF PROCUREMENT STRATEGY}

A client can take up a collaborative strategy for any given project, such as partnering regardless of the procurement method that is used. This type of strategy has been frequently used by clients with various projects to do. Using pre-defined indicators, the performance of both contractors and consultants can be examined for each of the projects they partook and then compared.

This strategy comes in handy specifically to monitor and evaluate incentive disbursement where appropriate (MORLEDGE et al., 2006). Once the establishment of primary strategy for a project has been made, then the following factors should be put into consideration when the most appropriate procurement strategy is being evaluated (ROWLINSON, 1999; MORLEDGE et al., 2006):

External factors - the potential effect of commercial, political, economic, social, legal and technological factors should be taken into consideration, which influence the client and their business, and the project team during project's lifecycle. For example, potential changes in interest rates, changes in legislation and so on.

Client resources - the procurement method which is used will be influenced by client's knowledge, the organisation's experience which brings about building projects and the environment within which it operates. The culture and nature of the organisation is influenced by the objectives of the client. A major aspect that should be considered is the level of client involvement in the project. 
INDEPENDENT JOURNAL OF MANAGEMENT \& PRODUCTION (IJM\&P)

http://www.ijmp.jor.br

v. 7, n. 4, October - December 2016

ISSN: 2236-269X

DOI: 10.14807/ijmp.v7i4.481

Project characteristics - The size, complexity, location and uniqueness of the project should be taken into consideration as this will influence time, cost and risk.

Ability to make changes - During the early project's early stages, the needs of the client should be pointed out ideally. This is occasionally impossible since alterations being introduced to a project may come as a result of changes in technology. On every occasion, changes in scope lead to increase costs and time, they occur during construction especially. It is imperative at the beginning of the project to regard the extent to which design can be completed and the changes occurring possibility.

Cost issues - The need for price assurance assessment should be attempted by the client and should be taking into consideration that there is a time delay from the initial cost target to when tenders are analysed. The cost at the time of tender will be influenced by the degree of design completion. If the price assurance is needed, then design must be finished before construction begins and design changes avoided.

By extension in construction, there are other strategies that allow involvement and collaboration as these are referred to in each procurement strategy descriptor. Therefore, the type of the business case and the prioritized objectives of the client determine the choice of such strategies used in the selection of procurement selection criteria to be adopted.

\section{Research method}

The participants in the survey comprised of general contractors, clients and consultants. A structured questionnaire was designed and administered to these categories of respondents to obtain industry wide views on the type of procurement systems being used in Nigeria and to ascertain the factors being considered in selecting appropriate procurement methods in achieving successful completion of projects.

The questionnaire is divided into three main sections. The first section obtained background information about the respondents and their respective organisations. The second part assessed the current procurement practices used and their selection criteria, while the last part sought to establish the performance of each of the procurement methods inter alia set parameters of cost, time and quality. 
INDEPENDENT JOURNAL OF MANAGEMENT \& PRODUCTION (IJM\&P)

http://www.ijmp.jor.br

v. 7, n. 4, October - December 2016

ISSN: 2236-269X

DOI: 10.14807/ijmp.v7i4.481

Prior to the administration of the questionnaire, a pilot study was carried out to identify and establish the decision criteria being used by the stakeholders in the industry in selecting procurement systems and to ascertain the subjectivity of those decision criteria.

This approach afforded us the opportunity of identifying the selection criteria currently in use for procurement systems selection which is in line with Luu et al. (2005) who used semi-structured interview. Therefore, to achieve a comprehensive understanding of how procurement systems are being selected and what factors are put into considerations in their choice of procurement options; those three categories of respondent were selected.

These categories of respondents were selected based on adequate understanding of different procurement systems being used in the industry as a result of their active participation; and sound practical experience and theoretical knowledge of different building procurement methods (NG; LUU; CHEN, 2002).

\subsection{Data Reliability}

According to Love (2002), reliability of data is linked to source of data and the recognition of the position held by the respondents to the survey. Hence, wellstructured questionnaires were self-administered to respondents who the researchers adjudged to possess requisite and detailed knowledge about the procurement process in the study area by virtue of their experience.

All the respondents sampled from the 420 questionnaires returned in the research, provided their background information that detailed their years of experience, involvement in the procurement process, as well as positions held within their organisations. A reliability analysis was conducted for the scales using Cronbach's Alpha.

The reliability of an instrument is meant to indicate the degree of consistency which measures the attributes it is supposed to be measuring (COHEN; MANION; MORRISON, 2000). The less variation an instrument generates in repeated measurements of an attribute, the higher its reliability. A rule of thumb that is relevant to most situations according to Cohen, Manion and Morrison (2000) and (GEORGE; MALLERY, 2003) is: $0.9 \leq \alpha \leq 1.0$ - Excellent; $0.8 \leq \alpha<0.9$ - Good; $0.7 \leq \alpha<0.8$ - 
INDEPENDENT JOURNAL OF MANAGEMENT \& PRODUCTION (IJM\&P)

http://www.ijmp.jor.br

v. 7, n. 4, October - December 2016

ISSN: 2236-269X

DOI: 10.14807/ijmp.v7i4.481

Acceptable; $0.6 \leq \alpha<0.7$ - Questionable; $0.5 \leq \alpha<0.6$ - Poor; and $0.0 \leq \alpha<0.5-$ Unacceptable.

The Cronbach's coefficient alpha was calculated for each construct of the questionnaire. The most identical values of alpha suggest that the mean and variances in the original construct do not vary much, and thus standardization does not make a great difference in alpha.

As summarised in Table 1 several of the scales that represent the constructs appear to have a good degree of reliability since each computed statistic is above 0.70, as substantiated by Cohen, Manion, and Morrison (2000) and George and Mallery (2003). Hence, it is proved that the questionnaire is valid, reliable and suitable for the population sample size.

Table 1: Reliability analysis using Cronbach's Alpha

\begin{tabular}{lcc}
\hline Construct & Cronbach's Alpha & Number of Items \\
\hline $\begin{array}{l}\text { Criteria for choosing a building project } \\
\text { contract method in order of priority for a } \\
\text { project }\end{array}$ & 0.880 & 17 \\
$\begin{array}{l}\text { Selected criteria as regards their strength for } \\
\text { choosing a building project in their respective } \\
\text { contract procurement methods }\end{array}$ & 0.866 & 6 \\
$\begin{array}{l}\text { Sources of conflicts in relation to projects } \\
\text { executed by contract procurement methods. }\end{array}$ & 0.790 & 12 \\
$\begin{array}{l}\text { Set parameters against each type of } \\
\text { procurement methods in order of priority }\end{array}$ & 0.792 & 15 \\
$\begin{array}{l}\text { Contract methods to recommend for types of } \\
\text { building project }\end{array}$ & 0.966 & 6 \\
\hline
\end{tabular}

\subsection{Data analysis and discussion of results}

\subsubsection{Level of use of procurement methods in FCT}

Various methods of selecting procurement system or strategy abounds in literature. However, according to Love et al. (1998), the choice of procurement method is becoming so broad due to projects complexity. There are quite a number of procurement systems identified to be in used in the study area and the frequency of their adoption or usage is presented in Table 2.

Table 2 shows that the respondents who were involved in the traditional contract method have the highest percentage of 33.3\% with a response count of 140 followed by those respondents that were mainly involved in design and build with a response count of 110 representing 26.2\%. Project management had a response 
INDEPENDENT JOURNAL OF MANAGEMENT \& PRODUCTION (IJM\&P)

http://www.ijmp.jor.br

v. 7, n. 4, October - December 2016

ISSN: 2236-269X

DOI: 10.14807/ijmp.v7i4.481

count of 96 representing 22.9\% while Contract Management and PPP have the lowest with counts of 56 and 18 representing $13.3 \%$ and $4.3 \%$ respectively.

In all, most of the respondent's organisations executed combination of traditional, design \& build, project management, management contracting and PPP. This result shows that the organisations were well acquainted with the various procurement methods, hence their capabilities to give accurate answers to the questions asked. Also, the result also confirms the study carried out by Babatunde et al. (2012), they ranked traditional method as the highest and most frequently used procurement method for procuring building projects in Nigeria.

Table 2: Level of use of procurement methods in FCT

\begin{tabular}{lcc}
\hline Level of use of procurement methods & Frequency & Percent \\
In FCT & & \\
\hline Traditional Contract Method (Design-Bid-Construct) & 140 & 33.3 \\
Design and Build & 110 & 26.2 \\
Project Management & 96 & 22.9 \\
Contract Management & 56 & 13.3 \\
PPP & 18 & 4.3 \\
Total & 420 & 100.0 \\
\hline
\end{tabular}

4.2.2. Mean Item Scores and ranks for procurement selection criteria

Table 3 shows the various procurement methods used in the execution of projects - traditional, design and build, project management, management contracting and public private partnerships methods in relation to the ranking of factors to make the projects successful.

The table shows that projects executed with traditional method have their first and most important contributor, factor, as 'when no causalities recorded to complete a project' ranked 1st and this was followed by 'completing a project within the estimated construction time' and 'when no conflicts recorded to complete a project' both with the same mean value ranked 2 nd at the same rank. Matters relating to 'completing a project within budgeted cost' were ranked 4th while the least ranked factor is 'satisfying with the quality of a project' ranked 5th.

In projects executed with design and build method, 'satisfying with the quality of a project' was ranked as the most important factor. This was followed by 'when no conflicts recorded to complete a project', 'when no causalities recorded to complete a project', 'completing a project within budgeted cost' and then 'completing a project within the estimated construction time'. 
INDEPENDENT JOURNAL OF MANAGEMENT \& PRODUCTION (IJM\&P)

http://www.ijmp.jor.br

v. 7, n. 4, October - December 2016

ISSN: 2236-269X

DOI: 10.14807/ijmp.v7i4.481

The aggregate ranking for projects executed with project management method indicates that 'completing a project within budgeted cost' was considered as the greatest factor. The factor 'when no causalities recorded to complete a project' was ranked second. 'Completing a project within the estimated construction time', 'when no conflicts recorded to complete a project' and 'satisfying with the quality of a project' were ranked as the $3 \mathrm{rd}$, 4th and 5th factors respectively.

For projects executed with Management contracting method like in the traditional method, 'when no causalities recorded to complete a project' was perceived to be the most important factor to make projects successful. 'When no conflicts recorded to complete a project' was ranked as 2nd, 'satisfying with the quality of a project' ranked 3rd, 'completing a project within the estimated construction time' ranked 4th, while 'completing a project within budgeted cost' was ranked the least.

Table 3: Mean item scores and ranks of procurement selection criteria

\begin{tabular}{lcccccccccc}
\hline Factor & $\begin{array}{l}\text { Mean } \\
(\mathrm{TM})\end{array}$ & $\begin{array}{l}\text { Rank } \\
(\mathrm{TM})\end{array}$ & $\begin{array}{l}\text { Mean } \\
\text { (DB) }\end{array}$ & $\begin{array}{l}\text { Rank } \\
(\mathrm{DB})\end{array}$ & $\begin{array}{l}\text { Mean } \\
(\mathrm{PM})\end{array}$ & $\begin{array}{l}\text { Rank } \\
(\mathrm{PM})\end{array}$ & $\begin{array}{l}\text { Mean } \\
(\mathrm{MC})\end{array}$ & $\begin{array}{l}\text { Rank } \\
\text { (MC) }\end{array}$ & $\begin{array}{l}\text { Mean } \\
(\mathrm{PP})\end{array}$ & $\begin{array}{l}\text { Rank } \\
\text { (PP) }\end{array}$ \\
\hline $\begin{array}{l}\text { Frequency of } \\
\begin{array}{l}\text { conflicts/dispute and } \\
\text { arbitration }\end{array}\end{array}$ & 2.23 & 2 & 2.23 & 2 & 2.11 & 4 & 2.28 & 2 & 1.82 & 1 \\
\hline $\begin{array}{l}\text { When no causalities } \\
\text { recorded to complete a } \\
\text { project }\end{array}$ & 2.36 & 1 & 2.20 & 3 & 2.32 & 2 & 2.55 & 1 & 1.77 & 2 \\
\hline Level of project quality & 2.13 & 5 & 2.40 & 1 & 2.02 & 5 & 2.23 & 3 & 1.77 & 2 \\
\hline Time certainty & 2.23 & 2 & 2.07 & 5 & 2.23 & 3 & 2.15 & 4 & 1.56 & 4 \\
\hline Cost certainty & 2.18 & 4 & 2.17 & 4 & 2.37 & 1 & 2.09 & 5 & 1.55 & 5 \\
\hline
\end{tabular}

The overall mean rank is given in Table 4. To further prove the reliability of the data collected by comparing the level of these factors for the various methods used among three groups of respondents (clients, consultants and contractors). From the findings, there are similarities from the results obtained. Even though, there is little variance this could not be avoided as a result of peculiarity of one method to another among the three groups (clients, consultants and contractors).

This is also an indication of the reliability of the data collected. Table 4 shows that "When no causalities recorded to complete a project would make a project successful" was rated highly significant to the success of a project. The factors that ranked 2nd "When no conflicts recorded to complete a project would make a project successful" while "Completing a project within the estimated construction time would 
INDEPENDENT JOURNAL OF MANAGEMENT \& PRODUCTION (IJM\&P)

http://www.ijmp.jor.br

v. 7, n. 4, October - December 2016

ISSN: 2236-269X

DOI: 10.14807/ijmp.v7i4.481

make a project successful" ranked 3rd, while "Completing a project within budgeted cost would make a project successful" and "Satisfying with the quality of a project would make a project successful" were ranked 4th together.

Table 4: Overall Mean Ranks for procurement selection criteria

\begin{tabular}{|c|c|c|}
\hline Project success criteria & Overall Mean & Rank \\
\hline When no causalities recorded to complete a project & 3.53 & 1 \\
\hline $\begin{array}{l}\text { When no conflicts recorded to complete a project would } \\
\text { Make a project successful }\end{array}$ & 3.32 & 2 \\
\hline $\begin{array}{l}\text { Completing project within the estimated construction time } \\
\text { Would make a project successful }\end{array}$ & 3.06 & 3 \\
\hline $\begin{array}{l}\text { Completing a project within budgeted cost would make a } \\
\text { project successful }\end{array}$ & 2.55 & 4 \\
\hline $\begin{array}{l}\text { Satisfying with the quality of a project would make a project } \\
\text { successful }\end{array}$ & 2.55 & 4 \\
\hline
\end{tabular}

Friedman test statistics was conducted among the three groups of respondents (client, consultants and contractors) to determine if there was any difference in response among the three groups (client, consultants and contractors). Friedman's chi-square has a value of 316.427 and a p-value of 0.000 as shown in Table 5 and is statistically significant. Hence, there is evidence that the distributions in response among the three groups of respondents (client, consultants and contractors) are different.

\begin{tabular}{ll}
\multicolumn{2}{c}{ Table 5: Friedman Test Statistics } \\
\hline $\mathbf{N}$ & $\mathbf{4 2 0}$ \\
Chi-Square & 316.427 \\
$\mathbf{D f}$ & 4 \\
Asymp. Sig. & .000 \\
\hline
\end{tabular}

\subsubsection{Choice of procurement method in terms of project value}

Table 6 shows that management contracting has the highest response count of 160 representing $38.1 \%$ on the type of procurement methods they will use in selecting the appropriate procurement method on a project size of $\$ 1$ - $\$ 10$ million, this was followed by the design and build with response count of 109 with $25.6 \%$, followed by the PPP with response count of 52 with 12.8\%, In addition, project management and traditional methods have the least response of 51 and 48 count accounting for $12.1 \%$ and $11.4 \%$ respectively. This implies that management contracting method is more reliable in terms of project size of $\$ 1-\$ 10$ million. 
DOI: 10.14807/ijmp.v7i4.481

Table 6: Project Size (N1-N10 million)

\begin{tabular}{lcc}
\hline Procurement method & Frequency & Percent \\
\hline Traditional Method & 48 & 11.4 \\
Design and Build & 109 & 25.6 \\
Project Management & 51 & 12.1 \\
Management contracting & 160 & 38.1 \\
PPP Total & 52 & 12.8 \\
$\quad$ Tol & 420 & 100.0 \\
\hline
\end{tabular}

Table 7 shows that design and build has the highest response with overwhelming count of 204 representing $48.6 \%$ followed by the project management with response count of 80 with $19.0 \%$, followed by the management contracting with response count of 59 with 14.1\%, In addition, PPP and traditional methods have the least response of 41 and 38 count accounting for $9.7 \%$ and $8.6 \%$ respectively. This implies that design and build method is more reliable in terms of project size of N11N99 million.

Table 7: Project Size (N11-N99 million)

\begin{tabular}{lcc}
\hline Procurement method & Frequency & Percent \\
\hline Traditional Method & 36 & 8.6 \\
Design and Build & 204 & 48.6 \\
Project Management & 80 & 19.0 \\
Management contracting & 59 & 14.1 \\
PPP & 41 & 9.7 \\
Total & 420 & 100.0 \\
\hline
\end{tabular}

Table 8 shows that design and build method has the highest response with a count of 198 representing $47.1 \%$ followed by the traditional method with response count of 112 with $26.7 \%$, followed by the management contracting with response count of 78 with $18.6 \%$. In addition, PPP and project management methods have the least response of 18 and 14 count accounting for $4.3 \%$ and 3.3\% respectively. This implies that design and build method is also more reliable in terms of project size of N100 million and above.

Table 8: Project Size (N100 million and above)

\begin{tabular}{lcc}
\hline Procurement method & Frequency & Percent \\
\hline Traditional Method & 112 & 26.7 \\
Design and Build & 198 & 47.1 \\
Project Management & 14 & 3.3 \\
Management contracting & 78 & 18.6 \\
PPP & 18 & 4.3 \\
Total & 420 & 100.0 \\
\hline
\end{tabular}


INDEPENDENT JOURNAL OF MANAGEMENT \& PRODUCTION (IJM\&P)

http://www.ijmp.jor.br

v. 7, n. 4, October - December 2016

ISSN: 2236-269X

DOI: 10.14807/ijmp.v7i4.481

\subsubsection{Prioritising project set parameters against procurement methods}

The overall mean rank given in Table 9 compared the duration of project based on the various methods used among all the three groups of respondents (clients, consultants and contractors). Table 9 shows that design and build was ranked first with an overall mean of 3.51, followed by management contracting ranked 2 nd with a mean score of 3.35 , while project management and traditional method were ranked 3rd and 4th with a mean score of 3.32 and 2.73 respectively.

While PPP was ranked 5th with 2.18 mean score. This implies that design and build is very beneficial as it relates to time as project parameters for considering a project successful. This is similar to the findings of Babatunde et al. (2010) that ranked time, cost and quality assurance as being the major considerations in procurement methods selection, with design and build taking preference, but contrary to the findings of Enekwechi (1993) that stated that traditional procurement method was the preferred choice in terms of cost, time and quality assurance.

This is not surprising as a result of the time difference between the two studies; there was improvement in the level of information at the disposal of construction industry players back in 2010 when compared with 1993 when Enekwechi's study was conducted.

Table 9: Overall Mean Ranks for Time

\begin{tabular}{llc}
\hline Procurement & Overall Mean & Rank \\
\hline Time for DB & 3.51 & 1 \\
\hline Time for MC & 3.35 & 2 \\
\hline Time for PM & 3.32 & 3 \\
\hline Time for TM & 2.73 & 4 \\
\hline Time for PPP & 2.18 & 5 \\
\hline
\end{tabular}

Table 10 shows that design and build was ranked 1st with an overall mean of 3.70 , followed by management contracting ranked 2nd with a mean score of 3.38 , while project management and traditional method were ranked 3rd and 4th with a mean score of 2.82 and 2.73 respectively. While PPP was ranked 5th with 2.73 mean score. This implies that design and build is still very beneficial as it relates to cost as a project parameters for considering a project successful. 
Table 10: Overall Mean Ranks for Cost

\begin{tabular}{|l|c|c|}
\hline $\begin{array}{l}\text { Procurement } \\
\text { Mean }\end{array}$ & Overall & Rank \\
\hline Cost for DB & 3.70 & 1 \\
\hline Cost for MC & 3.38 & 2 \\
\hline Cost for PM & 2.82 & 3 \\
\hline Cost for TM & 2.73 & 4 \\
\hline Cost for PPP & 2.37 & 5 \\
\hline
\end{tabular}

Table 11 ranks project parameters in terms of quality as against each type of procurement methods in order of priority among the groups of respondents (clients, consultants and contractors). The table shows that traditional method was ranked 1st with an overall mean of 3.69 , followed by design and build ranked 2 nd with a mean score of 3.29, while management contracting and project management were ranked 3rd and 4th with a mean score of 2.92 and 2.62 respectively. This implies that traditional method is very beneficial as it relates to quality as project parameters for considering a project successful.

Table 11: Overall Mean Ranks for Quality

\begin{tabular}{llc}
\hline Procurement & Overall Mean & Rank \\
\hline Quality for TM & 3.69 & 1 \\
Quality for DB & 3.29 & 2 \\
Quality for MC & 2.92 & 3 \\
Quality for PM & 2.62 & 4 \\
Quality for PPP & 2.48 & 5 \\
\hline
\end{tabular}

\section{DISCUSSION OF RESULTS}

The analysis of the survey carried out indicates that $78 \%$ constitutes the response rate of contractors, clients and consultants. This shows a good response to the survey. Traditional Contract Method (Design-Bid-Construct), Design and Build; and Public-Private Partnerships are the major building projects procurement methods in use as revealed by the pilot survey and subsequently captured by the questionnaires.

The respondents agreed that completing a project within estimated construction time, satisfaction with the quality of a project, when no conflicts recorded to complete a project and when no causalities recorded to complete a project are key criteria for selection procurement options. This finding is in agreement with the previously reported results by other researchers (e.g. LOVE et al., 1998; LUU et al., 2005). 
INDEPENDENT JOURNAL OF MANAGEMENT \& PRODUCTION (IJM\&P)

http://www.ijmp.jor.br

v. 7, n. 4, October - December 2016

ISSN: 2236-269X

DOI: 10.14807/ijmp.v7i4.481

However, reliability of the estimated cost, reliability on targeted time and finance arrangement offered should also be considered in the building procurement method as reported by Luu et al. (2005).

The results ascertained that traditional procurement method is the most frequently used procurement method for procuring building projects in Nigeria. This corroborated the assertion of Love et al. (1998) that argued that the most commonly used procurement arrangement by the client respondents is the traditional lump sum.

This is also in line with the submission of Adesanya (1992) and Enekwechi (1993) who considered traditional procurement technique as the most used method in Nigeria in executing construction project to achieve time and cost performance. The findings also supported the result of Rose and Manley (2011) who reported their research work based on forty-two case studies that $78 \%$ of management contracting projects were completed within or less than their budgeted cost compared with only $30 \%$ for traditional contracts.

The findings reflect the results of Jaafar and Nuruddin (2012) and Eyitope et al. (2012), who asserted that there is upward movement in the level of awareness of construction stakeholders to the benefits of other procurement methods as opposed to the traditional procurement method. On the criteria used in choosing building projects, design and build method as a type of procurement method is considered the best when the criteria to be considered include reliability of budgeted cost and reliability on estimated targeted construction time.

But if the criterion to consider is the minimization of total project time, from conception to completion, the best procurement method to use is the management contracting method. The study also showed that traditional method could be best explored in realising a project if the criteria to consider are how to manage effectively conflict on site and how to meet the required quality (ENEKWECHI, 1993).

As it relates to the choice of procurement method in terms of project value, the result of the findings showed that management contracting method is more reliable in bringingabout project with size ranging from N1 million to N10 million. For project size of N11 million to N99 million, the design and build method is adjudged to be the best in procuring such size of project. 
INDEPENDENT JOURNAL OF MANAGEMENT \& PRODUCTION (IJM\&P)

http://www.ijmp.jor.br

v. 7, n. 4, October - December 2016

ISSN: 2236-269X

DOI: 10.14807/ijmp.v7i4.481

This finding is analogous to NEDO (1985) that suggested that the management method offers price certainty because fees are paid on the actual cost of the work undertaken (LOVE et al., 1998). However, Maizon (1997) observed that the traditional system of procurement will be more beneficial in terms of cost and quality but to the detriment of time thus emphasising the obvious and observed overrun in time on construction project in Nigeria with its attendant cost consequences (OGUNSEMI; AJE, 2006).

Lastly, for project size of N100 million and above, the best procurement method as deduced from the results of the findings is also the design and build method to procure such size of project. This result relates well with the results of Maizon et al. (2006) and Peter et al. (2008), that contended that other procurement systems different from traditional system guarantee a better and efficient coordination of works, materials, manpower and plants, thus making construction time shorter compared to other procurement systems.

From the above, it could be deduced that irrespective of the construction project type that a client wants to engage on, the criteria used in selecting the appropriate procurement system for the project is duly put into consideration before selection. Cheong (2011), Brown (2010), Babatunde et al. (2010) and Eyitope et al. (2012) all confirmed the above when they revealed in their works that client or project manager tends to adopt any procurement to any type of project that will enhance the achievement of adequate project performance in terms of time, cost and quality specification.

In measuring project success, these three factors are considered; they are the three most important parameters of project performance. It should be noted that in today's highly competitive and uncertain business environment, clients are demanding better value from their investment. They want their projects to be completed on time, within the estimated cost and the right quality.

\section{CONCLUSION}

An effective and efficient procurement method is sine qua non to improving contract administration and delivery. The results of the study showed that construction industry is a demanding work environment where many projects are 
INDEPENDENT JOURNAL OF MANAGEMENT \& PRODUCTION (IJM\&P)

http://www.ijmp.jor.br

v. 7, n. 4, October - December 2016

ISSN: 2236-269X

DOI: $10.14807 /$ ijmp.v7i4.481

carried out, every construction project type has its oddity, which must be watched out for before selecting a procurement method suitable for a project.

Traditional, design \& build, project management, contract management and public private partnerships methods considered the most commonly applied type of procurement methods available, hence the focus of this paper. Among these identified procurement methods, respondents considered design and build system as being the best and most effective method.

The fact that others had low response, do not infer that they are not used effectively for project execution. From the responses, there were different criteria for selecting procurement methods. Six most commonly considered criteria were identified and from the results, the quality determines the type of procurement method to be used, to the respondents, to achieve adequate quality of project, traditional and design and build methods are most suitable, also to achieve early completion of project, design and build method is most suitable.

To minimize conflict throughout the construction period, project management and management contracting method were recommended, for cost certainty, the method to adopt are design and build and management contracting methods. When project involves risk transfer, the method to use could be PPP or management contracting methods so that the risk involved can be managed effectively by the construction stakeholders.

Also PPP can be used when funds for a project are not readily available and need for the project cannot be overemphasized. However, effect of the choice of procurement system on building project procurement shows that traditional, design \& build and management oriented can enhance project quality and responsibility division.

\section{LIMITATIONS}

Every research has its limitations and this current study is no exception. The study examines the procurement selection criteria for projects in the public sector in the Nigerian construction industry. However, the data set employed in the study exhibit a high level of reliability, the data is only obtained from stakeholders based in Abuja, the Federal Capital Territory of Nigeria. Therefore, there is the need to 
INDEPENDENT JOURNAL OF MANAGEMENT \& PRODUCTION (IJM\&P)

http://www.ijmp.jor.br

v. 7, n. 4, October - December 2016

ISSN: 2236-269X

DOI: 10.14807/ijmp.v7i4.481

exercise caution when generalizing the results due to the geographical spread of the country.

Also, a research pro forma attached to the questionnaire for respondents to provide details of project characteristics such as initial and final cost and time respectively of the projects procured using different procurement methods was not completed by all the respondents, hence limiting the robustness of the study.

\section{AREA OF FURTHER STUDY}

The research work suggests a further study to be conducted in this angle of knowledge, by looking into an appraisal of Public Private Partnership procurement method in the midst of fast tracking procurement system to achieve accelerated project delivery.

\section{REFERENCES}

ADESANYA, O. M. (1992) Management Contracting Concepts and Nigeria's Construction Industry. A Paper Presented At the Joint Seminar on Management Contract of Quantity Surveyors Registration Board of Nigeria and Nigerian Institute of Quantity (18 ${ }^{\text {th }}$ September 1992, Lagos)

BABATUNDE, S. O.; OPAWOLE, A.; UJADDUGHE, I. C. (2010). An Appraisal of Procurement Methods in the Nigerian Construction Industry. Civil Engineering Dimension, v.12, p. 56-58.

BOWEN, P. A.; PEARL, R. G.; EDWARDS, P. J. (1999). Client briefing processes and procurement method selection: a South African study. Engineering,

Construction and Architectural Management, v. 6, n. 2, p. 91-104.

BROWN, J. T. (2010). Procurement issues with construction build-up in Nigeria. Retrieved from; http://www.bloggeddown-inprocuremnt.blogspot.com (Accessed on the $21^{\text {st }}$ of December 2012)

CHEONG, Y. Y. (2011) Accelerating Change in the Malaysian Construction Industry through Procurement method. Retrieved from;

www.academia.edu/233011/accelration.html/ (Accessed On the $11^{\text {th }}$ December 2012)

COHEN, L.; MANION, L.; MORRISON, K. (2000). Research Methods in

Education. New York: Routledge Falmer.

ENEKWECHI, C. O. (1993). Construction Management as a Contract Procurement System', Builders Magazine, v. vii, n. 6, p. 17-18

GEORGE, D.; MALLERY, P. (2003). SPSS for window Step by Step. Fourth edition. Retrieved from; iase-web.org/../SERJ2 (2)_Mills.pdf(Accessed on the $26^{\text {th }}$ October, 2012).

GORDON, C. M. (1994). Choosing appropriate construction contracting method.

Journal of Construction, Engineering and Management, v. 120, n. 1, p. 196-210. 
INDEPENDENT JOURNAL OF MANAGEMENT \& PRODUCTION (IJM\&P)

http://www.ijmp.jor.br

v. 7, n. 4, October - December 2016

ISSN: 2236-269X

DOI: 10.14807/ijmp.v7i4.481

JAAFAR, M.; NURUDDIN, A. R. (2012). The development of Public and Private Construction procurement system in the Malaysian construction industry. Journal of Design and Built environment, v. 11, p. 1-11.

LOVE, P. E. D.; SKITMORE, R. M.; EARL, G. (1998). Selecting an appropriate procurement method for a building project. Construction Management and Economics, v. 16, p. 221-223.

LUU, D. T.; NG, S. T.; CHEN, S. E. (2005). Formulating procurement selection criteria through case based reasoning approach. Journal of Computing in Civil Engineering, v. 19, n.3, 269-276.

MAIZON, H.; MELISSA, C. Y.; NG, C. Y.; NG, S. H.; SHIM, M. H.; TAY, L. Y. (2006). Factors Influencing the Selection of Procurement Systems by Clients. Proceeding of International Conference on Construction Industry 2006, Padang, Indonesia, $21^{\text {st }}$ June - 25th June 1-10.

MASTERMAN, J. W. E.; GAMESON, R. N. (1994). Client characteristics and needs in relation to their selection of building procurement systems. Proceedings of CIB W-92 International Procurement Symposium, 'East Meets West', Department of Surveying, University of Hong Kong, 4-7 December 1994.

MATHONSI, M. O.; THWALA, W. D. (2012), Factors influencing the selection of procurement systems in the South African construction industry. African Journal of Business Management, v. 6, n. 3, p. 583-594.

MORTLEDGE, R., SMITH, A. AND KASHIWAGI, D.T. (2006). Building Procurement. Oxford: Blackwell.

National Economic Development Office (NEDO) (1985). Think About Building. London: NEDC

NG, T. S.; LUU, D. C.; CHEN, S. E. (2002). Decision criteria and their subjectivity in construction Procurement selection. The Australian Journal of Construction Economics and Building, v. 2, n. 1, p. 70-80.

NOAUM, S. G. (1994). Critical analysis of time and cost of management and traditional contracts. Journal of Construction Engineering and Management, $v$. 120 , n. 4, p. 687-705.

OGUNSEMI, D. R.; AJE I. O. (2006), A Model for Contractor Selection in Nigeria. Journal of Financial Management of Property and Construction, v. 11, n. 1, p. 33- 43.

MAIZON, H. (1997). Clients' Criteria on the Choice of Procurement Systems - A Malaysian Experience. Proceedings of CIB W92: Procurement - A Key to Innovation. Montreal. 273-284.

OJO, A. E.; GBADEBO M. A. (2012) Critical Selection Criteria for Appropriate Procurement Strategy for Project Delivery in Nigeria. Journal of Emerging Trends in Economics and Management Sciences (JETEMS), v. 3, n. 5, p. 422-428.

ROWLINSON, S. (1999). Selection criteria. In. S. Rowlinson, and P. McDermott, Procurement Systems: A Guide to Best Practice in Construction. London: E \& F Spon 
SKITMORE, R. M.; MARSDEN, D. E. (1988). Which procurement system? Towards a universal procurement selection technique. Construction Management and Economics, v. 6, p. 71-89.

TURNER, A. (1990). Building Procurement. London: Macmillan Surveying Series 